\title{
Identifikasi Faktor-Faktor yang Mempengaruhi Perceived Value Terhadap Niat Adopsi Mobil Ramah Lingkungan
}

\author{
Atika Isti Aditya Putri dan Janti Gunawan \\ Departemen Manajemen Bisnis, Institut Teknologi Sepuluh Nopember (ITS) \\ e-mail: janti_g@mb.its.ac.id
}

\begin{abstract}
Abstrak-Industri otomotif merupakan industri yang memainkan peran penting dalam perekonomian dan ketenagakerjaan Indonesia. Namun, peran industri otomotif tidak hanya dilihat dari kedua aspek tersebut tetapi juga dari aspek lingkungan. Maka munculah tren kendaraan ramah lingkungan salah satunya Mobil Low Carbon Emission Vehicle (LCEV). Namun, penjualan mobil Low Carbon Emission Vehicle (LCEV) tergolong sedikit karena peminat mobil masih rendah. Masyarakat masih enggan beralih menggunakan mobil LCEV karena berbagai faktor. Oleh karena itu, penelitian ini bertujuan untuk mengidentifikasi faktor yang mempengaruhi masyarakat Indonesia dalam mengadopsi mobil LCEV. Tujuan penelitian ini diselesaikan dengan menggunakan metode Partial Least Square - Structural Equation Model (PLS-SEM). Pengumpulan data dilakukan dengan penyebaran online survey pada 99 sampel menggunakan teknik snowball, purposive dan convenience sampling. Penelitian yang mengadopsi model Value Based Adoption Model (VAM) ini menghasilkan temuan bahwa bahwa operational economic benefit, eco-friendly benefit, dan driving enjoyment benefit berpengaruh positif signifikan sedangkan charging risk berpengaruh negatif terhadap perceived value pada mobil Low Carbon Emission Vehicle (LCEV). Disisi lain, non-financial policies memoderasi hubungan perceived value secara positif terhadap niat adopsi.
\end{abstract}

Kata Kunci-Perceived Value, Niat Adopsi, Mobil Low Carbon Emission Vehicle (LCEV), Value Based Adoption Model (VAM).

\section{PENDAHULUAN}

$\mathbf{I}_{\mathrm{p}}^{\mathrm{s}}$ NDUSTRI otomotif merupakan industri yang memainkan peran penting dalam perekonomian dan ketenagakerjaan Indonesia. Di bidang perekonomian, kontribusi industri otomotif terhadap Produk Domestik Bruto (PDB) Indonesia mencapai 10,16\% di tahun 2018 [1]. Hal ini sejalan dengan nilai ekspor di industri otomotif yang mengalami kenaikan sebesar 7\% pada tahun 2018 [2]. Di bidang ketenagakerjaan, industri ini mampu menyerap tenaga kerja Indonesia sebanyak 350 ribu tenaga kerja langsung dan 1,2 juta tenaga kerja tidak langsung [1]. Industri yang identik dengan kendaraan bermotor dan reparasinya ini diharapkan dapat membantu Indonesia untuk maju dan bersaing di pasar global. Namun, peran industri otomotif tidak hanya diliat dari kedua aspek diatas tetapi juga pada aspek lingkungan yaitu kemampuan industri untuk mengurangi emisi karbon dioksida (CO2) dan menjaga lingkungan berkelanjutan.

Maka munculah tren kendaraaan ramah lingkungan salah satunya mobil. Di Indonesia, mobil ramah lingkungan terbagi menjadi dua kategori yaitu mobil Low Cost Green Car (LCGC) dan Low Carbon Emission Vehicle (LCEV). Meskipun memiliki nilai yang baik dari aspek lingkungan, namun permintaan akan produk LCEV masih terg olong sedikit. Bahkan, salah satu market leader, PT Toyota Astra Motor (TAM) hanya mampu menjual 2.100 unit dari 13 juta unit penjualan mobil hybrid di pasar global dalam sepuluh tahun terakhir [3]. Penjualan di Indonesia hanya sebesar 0,016\% jika dibandingkan dengan penjualan TAM di pasar global. Sedikitnya penjualan ini menunjukkan bahwa pasar mobil LCEV di Indonesia masih jauh dibawah rata-rata. Menurut Solidiance, ada beberapa faktor penyebab masyarakat masih enggan menggunakan mobil LCEV seperti daya tempuh (jelajah), keberadaan infrastruktur SPLU (Stasiun Pengisian Listrik Umum) yang masih sedikit hingga belum adanya layanan cicilan oleh perusahaan finansial [4].

Dalam mengadopsi produk baru, khususnya mobil masyarakat mempertimbangkan manfaat (benefit) dan risiko (risk) dari produk tersebut [5], mengingat bahwa mobil ialah kebutuhan sekunder [6]. Manfaat yang sering ditawarkan seperti hemat bahan bakar, komponen mobil yang tahan lama, mampu mengurangi emisi $\mathrm{CO} 2$ dan kenikmatan saat berkendara [5]. Jika dilihat dari segi manfaat, mobil LCEV memiliki berbagai keuntungan daripada mobil konvensional. Namun, mobil LCEV juga memiliki kekurangan yang dikenal sebagai risiko yang akan diterima [5]. Munculnya risiko menjadi faktor penghambat yang membentuk sikap negatif dan menurunkan niat adopsi [7]. Risiko yang sering dihadapi ialah biaya penggantian baterai yang relatif mahal, daya tempuh yang pendek dan kurangnya infrastruktur pengisian daya yang disediakan [8][9].

Padahal pemerintah telah memberikan dukungan melalui PLN (Perusahaan Listrik Negara) dengan menyediakan berupa SPLU (Stasiun Pengisian Listrik Umum) sekitar 7.000 unit yang tersebar di seluruh Indonesia [10], namun infrastruktur yang ada fokus pada kota-kota besar sehingga masyarakat akan berpikir ulang untuk mengadopsi mobil LCEV. Kurangnya infrastruktur inilah yang menjadi alasan utama masyarakat enggan mengadopsi mobil LCEV [11]. Keengganan masyarakat dalam mengadopsi mobil LCEV menjadi tugas besar industri otomotif bersama pemerintah dalam mewujudkan kendaraan masa depan yang ramah lingkungan di Indonesia. Industri otomotif harus kreatif dan mampu memanfaatkan tren yang ada saat ini, yaitu tren pada produk ramah lingkungan [12]. Karena sifat pro-lingkungan (pro-environmental traits) memiliki pengaruh positif terhadap sikap konsumen pada mobil LCEV, bahkan masyarakat dengan sifat pro-lingkungan yang tinggi cenderung mau mengadopsi mobil berjenis hybrid [13][14].

Maka penelitian ini diarahkan untuk mengidentifikasi faktor-faktor yang mempengaruhi perceived value terhadap 
niat adopsi mobil ramah lingkungan yaitu mobil LCEV yang di moderasi oleh dukungan pemerintah dan sifat prolingkungan pada mobil LCEV. Penelitian ini diharapkan dapat memberi implikasi manajerial bagi industri otomotif untuk mengetahui nilai-nilai apakah yang ingin didapatkan oleh masyarakat potensial baik dari sisi manfaat ataupun risiko yang menghambat niat adopsi mobil LCEV. Dengan mengetahui nilai tersebut, industri otomotif dapat menyusun strategi pemasaran yang tepat bagi masyarakat potensial yang bersedia mengadopsi mobil LCEV.

\section{II.TINJAUAN PUSTAKA}

\section{A. Mobil Low Carbon Emission Vehicle (LCEV)}

Mobil LCEV ialah mobil rendah emisi yang dikenalkan untuk menjaga lingkungan berkelanjutan dan memerangi masalah perubahan iklim yang didukung oleh penggunaan energi baterai dan listrik [15]. Mobil Low Carbon Emission Vehicle (LCEV) terbagi menjadi beberapa jenis yaitu Hybrid, Plug-In, Battery, dan Fuel Cell Electric Vehicle.

\section{B. Value Based Adoption Model (VAM)}

VAM ialah model yang menjelaskan penerimaan teknologi informasi dan komunikasi [16]. VAM melihat manfaat (kegunaan dan kenikmatan) dan pengorbanan sebagai faktor utama dari nilai yang dirasakan kemudian dianalisis niat untuk menggunakan. Teori ini didasarkan pada paradigma biaya dan manfaat yang mencerminkan proses pengambilan keputusan [16].

\section{Perceived Value}

Perceived value adalah penilaian keseluruhan oleh konsumen terhadap utilitas suatu produk atau layanan berdasarkan persepsi tentang apa yang diterima dan apa yang diberikan [17]. Perceived value mengacu pada nilai yang dirasakan sebagai gap antara jumlah yang telah dibayarkan dengan kualitas aktual yang didapatkan. Perceived value terdiri dari perceived benefit dan perceived risk [5].

\section{D.Perceived Benefit}

Perceived benefit merupakan faktor psikologis yang penting dan berdampak pada penerimaan konsumen terhadap produk baru dan inovatif [18]. Menurut Kim et al. (2018), perceived benefit pada mobil Low Carbon Emission Vehicle (LCEV), terbagi menjadi tiga yaitu operational economic benefit, eco-friendly benefit dan driving enjoyment benefit.

\section{E. Perceived Risk}

Perceived risk ialah risiko yang mengacu pada utilitas negatif yang diharapkan dan diasosiasikan konsumen dengan pembelian produk atau layanan tertentu [7]. Menurut Kim et al. (2018), perceived risk pada mobil Low Carbon Emission Vehicle (LCEV) terbagi menjadi tiga yaitu price and battery cost, technological performance risk dan charging risk.

\section{F. Pro-Environmental Traits (Sikap Pro-Lingkungan)}

Pro-environmental traits merupakan sikap sejauh mana seseorang (individu) memandang diri sendiri sebagai seorang pecinta lingkungan [19]. Pro-environmental traits

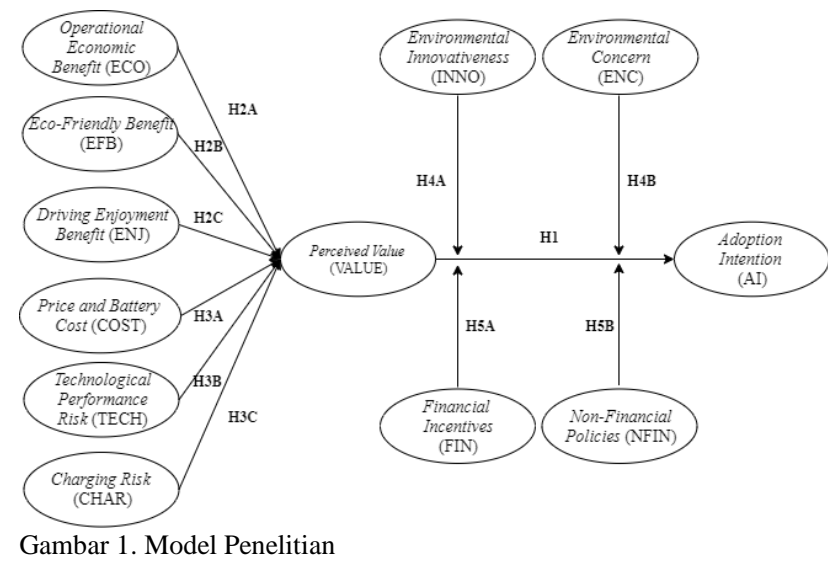

memiliki pengaruh positif pada sikap konsumen terhadap mobil LCEV [14]. Sikap pro-lingkungan yang dimiliki oleh seseorang dapat dilihat dari environmental concern dan environmental innovativeness yang dimiliki [5].

\section{G.Goverment Support (Dukungan Pemerintah)}

Dukungan pemerintah menjadi instrumen penting dan efisien untuk mempromosikan permintaan pasar dan membangun infrastruktur guna mencegah kegagalan pasar yang menawarkan barang publik dan nilai sosial yang tinggi seperti mobil LCEV [20]. Dukungan yang diberikan oleh pemerintah terbagi menjadi insentif keuangan seperti pengurangan pajak dan kebijakan non keuangan seperti perluasan infrastruktur pengisian daya [5].

\section{H.Niat Adopsi}

Niat adopsi didefinisikan sebagai kecendurungan untuk membeli suatu produk baru dalam kategori tertentu setelah produk muncul di pasar [21]. Niat adopsi pada mobil LCEV dipengaruhi oleh atribut instrumental produk seperti harga, keandalan, biaya operasional, kinerja, driving range, dan waktu pengisian ulang [22].

\section{METODOLOGI PENELITIAN}

\section{A. Desain dan Sampel Penelitian}

Penelitian ini menggunakan pendekatan kuantitatif dengan jenis conclusive-descriptive dengan tujuan untuk menguji sebuah hubungan dan hipotesis yang spesifik [23] dan mendeskripsikan karateristik masyarakat Indonesia yang berniat mengadopsi mobil LCEV. Pengumpulan data dilakukan dengan online survey secara multiple crosssectional, yang dilakukan pada satu periode terhadap berbagai sampel dalam populasi. Sampel penelitian merupakan Masyarakat Indonesia yang pernah mengendarai mobil LCEV pada satu tahun terakhir. Waktu satu tahun terakhir digunakan karena merupakan waktu yang wajar dalam mengingat nilai yang dirasakan dalam menggunakan mobil Low Carbon Emission Vehicle (LCEV) tersebut. Jumlah minimal sampel yang diperlukan ialah 60 sampel, mengacu pada konsep rule of thumb, yaitu jumlah maksimum panah yang menunjuk pada variabel laten [24].

\section{B. Pengumpulan Data}

Data primer pada penelitian ini diperoleh dari online suvey menggunakan Google Formulir untuk mendapatkan responden yang lebih banyak dan luas. Metode pengisian 
kuesioner dilakukan secara self-administered yaitu responden mengisi kuesioner secara mandiri. Sebelum menyebarkan data secara masif, dilakukan pilot test pada 33 responden pada 17 November hingga 23 November 2019. Pilot test dilakukan untuk memberikan input bagi perbaikan item pertanyaan sehingga lebih mudah dipahami. Pengumpulan data penelitian secara masif dilakukan pada 24 November hingga 13 Desember 2019 menggunakan multiple data collection yaitu convenience, snowball dan purposive sampling dengan memanfaatkan media sosial dan memperoleh 99 data valid. Data yang valid akan dilanjutkan menuju tahap pengolahan dan analisis data.

\section{Model dan Hipotesis Penelitian}

Data yang telah terkumpul kemudia diolah menggunakan software SPSS 23 dan Microsoft Excel untuk analisis data demografi responden dan uji asumsi klasik. Selanjutnya pengujian hipotesis dilakukan menggunakan software SMART PLS 3. Variabel yang digunakan dalam penelitian ini mengadaptasi penelitian Kim et al. (2018) dengan variabel independen berupa operational economic benefit (manfaat ekonomi operasional), eco-friendly benefit (manfaat ramah lingkungan), driving enjoyment benefit (manfaat kenikmatan berkendara), price and battery cost (harga dan biaya baterai), technological performance risk (risiko kinerja teknologi) dan charging risk (risiko pengisian). Variabel mediator pada penelitian ini ialah perceived value dan variabel moderator ialah environmental innovativeness (inovasi lingkungan), environmental concern (kepedulian lingkungan), financial incentives (insentif keuangan) dan non-financial policies (kebijakan nonkeuangan). Sedangkan variabel dependen yang digunakan ialah niat adopsi. Berikut merupakan model yang digunakan dalam penelitian ini :

Berdasarkan model penelitian pada Gambar 1, terdapat 11 hipotesis yang diajukan dalam penelitian ini, yaitu:

H1. Perceived value berpengaruh positif terhadap niat adopsi pada mobil Low Carbon Emission Vehicle (LCEV).

H2A. Operational economic benefit berpengaruh positif terhadap perceived value pada mobil Low Carbon Emission Vehicle (LCEV).

H2B. Eco-friendly benefit berpengaruh positif terhadap perceived value pada mobil Low Carbon Emission Vehicle (LCEV).

H2C. Driving enjoyment benefit berpengaruh positif terhadap perceived value pada mobil Low Carbon Emission Vehicle (LCEV).

H3A. Price and battery cost berpengaruh negatif terhadap perceived value pada mobil Low Carbon Emission Vehicle (LCEV).

H3B. Technological performance risk berpengaruh negatif terhadap perceived value pada mobil Low Carbon Emission Vehicle (LCEV).

H3C. Charging risk berpengaruh negatif terhadap perceived value pada mobil Low Carbon Emission Vehicle (LCEV).

H4A. Environmental innovativeness) secara positif memoderasi hubungan antara perceived value dan niat adopsi mobil Low Carbon Emission Vehicle
Tabel 1.

Outer Model

\begin{tabular}{cll}
\hline \hline No. & \multicolumn{1}{c}{ Evaluasi } & \multicolumn{1}{c}{ Kriteria } \\
\hline 1. & $\begin{array}{l}\text { Convergent } \\
\text { Validity }\end{array}$ & $\begin{array}{l}\text { Outer loading } \geq 0,5 \text { (Diterima) } \\
\text { dan Outer loading }>0,7 \text { (Ideal) } \\
\text { Square Root of Average (AVE) }>\end{array}$ \\
2. & $\begin{array}{l}\text { Discriminant } \\
\text { Validity }\end{array}$ & $\begin{array}{l}\text { Korelasi antar variabel dan } \\
\text { Average Variance Extracted (AVE) } \\
\geq 0,5\end{array}$ \\
& Internal & Cronbach's Alpha $\geq 0,6$ dan \\
3 & Consistency & Composite Reliability (CR) $\geq 0,7$ \\
& Reliability &
\end{tabular}

\begin{tabular}{|c|c|c|c|}
\hline \multicolumn{4}{|c|}{$\begin{array}{l}\text { Tabel } 2 . \\
\text { Inner Model }\end{array}$} \\
\hline No. & Evaluasi & \multicolumn{2}{|c|}{ Kriteria } \\
\hline 1. & Koefisien $\mathrm{R}^{2}$ & \multicolumn{2}{|c|}{$\begin{array}{l}\text { Substansial atau kuat }(0,75) \text {; Moderat } \\
(0,50) \text {; Lemah }(0,25)\end{array}$} \\
\hline 2. & $\begin{array}{l}\text { Relevansi } \\
\text { prediksi }\end{array}$ & \multirow{2}{*}{\multicolumn{2}{|c|}{$\begin{array}{l}\text { Apabila } \mathrm{Q}^{2} \text { semakin mendekati nilai } \\
1 \text {, model memiliki prediksi relevan } \\
\text { Koefisien bernilai positif } \\
\text { menggambar-kan hubungan yang } \\
\text { positif dan sebaliknya }\end{array}$}} \\
\hline 3. & $\begin{array}{l}\text { Path } \\
\text { Coefficients }\end{array}$ & & \\
\hline \multicolumn{4}{|c|}{$\begin{array}{c}\text { Tabel } 3 . \\
\text { Data Profil Responden }\end{array}$} \\
\hline & fil Responden & Jumlah & Frekuensi (\%) \\
\hline \multicolumn{4}{|c|}{ Jenis Mobil LCEV } \\
\hline \multicolumn{2}{|c|}{ Mobil Hybrid } & 62 & 63 \\
\hline \multicolumn{2}{|c|}{ Mobil Plug-in Hybrid } & 13 & 13 \\
\hline \multicolumn{2}{|c|}{ Mobil Listrik } & 24 & 24 \\
\hline \multicolumn{2}{|c|}{ TOTAL } & 99 & 100 \\
\hline
\end{tabular}

\section{(LCEV).}

$H 4 B$. Environmental concern secara positif memoderasi hubungan antara perceived value dan niat adopsi mobil Low Carbon Emission Vehicle (LCEV).

H5A. Financial incentives secara positif memoderasi hubungan antara perceived value dan niat adopsi mobil Low Carbon Emission Vehicle (LCEV).

H5B. Non-financial incentives secara positif memoderasi hubungan antara perceived value dan niat adopsi mobil Low Carbon Emission Vehicle (LCEV).

\section{D.PLS-SEM}

Analisis PLS SEM merupakan SEM berbasis variance yang bertujuan untuk menguji hubungan prediktif antar konstruk dengan melihat apakah ada hubungan atau pengaruh antar konstruk tersebut. Konsekuensi logis penggunaan PLS-SEM ialah pengujian dapat dilakukan tanpa adanya dasar teori yang kuat, dengan mengabaikan beberapa asumsi dan parameter ketepatan model prediksi dilihat dari nilai koefisien determinasi $\left(\mathrm{R}^{2}\right)$. Terdapat dua evaluasi model yang digunakan dalam analisis PLS-SEM sebagai berikut.

\section{1) Model Pengukuran (Outer Model)}

Evaluasi model pengukuran dilakukan untuk menilai validitas dan reliabilitas pada model penelitian. Ukuran statistik yang digunakan untuk mengevaluasi outer model dapat dilihat pada Tabel 1.

\section{2) Model Struktural (Inner Model)}

Pada tahapan ini, hipotesis dievaluasi tingkat kecocokannya. Tahap ini dilakukan untuk membedakan antara hipotesis kausal yang relevan dan yang tidak mendukung bukti empiris. Ukuran statistik yang digunakan 
Tabel 4.

Data Profil Responden (Lanjutan)

\begin{tabular}{|c|c|c|}
\hline Profil Responden & Jumlah & Frekuensi (\%) \\
\hline \multicolumn{3}{|l|}{ Jenis Mobil LCEV } \\
\hline Mobil Hybrid & 62 & 63 \\
\hline Mobil Plug-in Hybrid & 13 & 13 \\
\hline Mobil Listrik & 24 & 24 \\
\hline TOTAL & 99 & 100 \\
\hline \multicolumn{3}{|l|}{ Jenis Kelamin } \\
\hline Laki-Laki & 82 & 83 \\
\hline Perempuan & 17 & 17 \\
\hline TOTAL & 99 & 100 \\
\hline \multicolumn{3}{|l|}{ Usia } \\
\hline$<18$ tahun & 0 & 0 \\
\hline 18-25 tahun & 66 & 67 \\
\hline 26-35 tahun & 16 & 16 \\
\hline $36-45$ tahun & 4 & 4 \\
\hline 46-59 tahun & 12 & 12 \\
\hline$>59$ tahun & 1 & 1 \\
\hline TOTAL & 99 & 100 \\
\hline \multicolumn{3}{|c|}{ Jenjang Pendidikan Terakhir } \\
\hline Sekolah Menengah & 33 & 33 \\
\hline Diploma & 9 & 9 \\
\hline Sarjana & 48 & 49 \\
\hline Pascasarjana & 9 & 9 \\
\hline TOTAL & 99 & 100 \\
\hline \multicolumn{3}{|l|}{ Domisili Provinsi } \\
\hline DKI Jakarta & 30 & 30 \\
\hline Banten & 5 & 5 \\
\hline Jawa Barat & 13 & 13 \\
\hline Jawa Tengah & 2 & 2 \\
\hline DI Yogyakarta & 3 & 3 \\
\hline Jawa Timur & 40 & 41 \\
\hline Bali & 1 & 1 \\
\hline Kepulauan Riau & 1 & 1 \\
\hline Sumatera Utara & 1 & 1 \\
\hline Lampung & 1 & 1 \\
\hline Kalimantan Selatan & 2 & 2 \\
\hline TOTAL & 99 & 100 \\
\hline \multicolumn{3}{|l|}{ Domisili Kota } \\
\hline Jakarta Pusat & 9 & 9 \\
\hline Jakarta Barat & 3 & 3 \\
\hline Jakarta Timur & 2 & 2 \\
\hline Jakarta Utara & 3 & 3 \\
\hline Jakarta Selatan & 9 & 9 \\
\hline Tangerang Selatan & 7 & 7 \\
\hline Depok & 3 & 3 \\
\hline Bogor & 1 & 1 \\
\hline Bandung & 4 & 4 \\
\hline Bekasi & 7 & 7 \\
\hline Semarang & 2 & 2 \\
\hline Sleman & 2 & 2 \\
\hline Yogyakarta & 1 & 1 \\
\hline Surabaya & 24 & 25 \\
\hline Sidoarjo & 4 & 4 \\
\hline Malang & 6 & 6 \\
\hline Madiun & 1 & 1 \\
\hline
\end{tabular}

untuk mengevaluasi model strukural dapat dilihat pada Tabel 2 .

\section{ANALISIS DAN DISKUSI}

\section{A. Data Profil Responden}

Berikut merupakan analisis deskriptif yang ditampilkan pada Tabel 3 dan Tabel 4.

\section{B. Uji Asumsi Klasik}

Uji asumsi juga digunakan untuk melihat data yang hilang dan data yang berbeda dibandingkan data lainnya agar data yang didapatkan lebih valid dan akurat. Dalam penelitian ini,
Tabel 5.

Uji Hipotesis

\begin{tabular}{cccc}
\hline \hline Hipotesis & $\begin{array}{c}\text { Path } \\
\text { Coefficient }\end{array}$ & P Values & Hipotesis \\
\hline H1 & 0.230 & 0.033 & Diterima \\
H2A & 0.186 & 0.014 & Diterima \\
H2B & 0.147 & 0.038 & Diterima \\
H2C & 0.330 & 0.000 & Diterima \\
H3A & 0.158 & 0.167 & Ditolak \\
H3B & -0.131 & 0.065 & Ditolak \\
H3C & -0.403 & 0.001 & Diterima \\
H4A & -0.021 & 0.797 & Ditolak \\
H4B & -0.034 & 0.714 & Ditolak \\
H5A & -0.216 & 0.052 & Ditolak \\
H5B & 0.202 & 0,019 & Diterima \\
\hline \hline
\end{tabular}

uji asumsi klasik yang dilakukan ialah uji missing data, uji outliers, uji normalitas, uji linearitas, uji homoskedastisitas dan uji multikolinearitas. Setelah dilakukan pengujian, 99 lulus semua uji asumsi klasik sehingga uji model dan hipotesis dapat dilakukan.

\section{Uji Model Pengukuran dan Struktural}

Beberapa indikator dalam uji outer model antara lain, yaitu :

1) Convergent Validity

Keseluruhan data memiliki nilai outer loading pada rentang 0,622 hingga 0,937 sehingga setiap indikator telah menujukkan korelasi terhadap konstruknya. Selanjutnya ialah nilai AVE, dari 12 variabel laten terdapat variabel operational economic benefit yang memiliki nilai $<0,5$ sehingga perlu dilakukan reduksi untuk meningkatkan nilai AVE.

2) Discriminant Validity.

Uji ini dilakukan dengan melihat nilai cross loading. Dalam penelitian ini, setiap variabel memiliki korelasi yang baik ditunjukkan nilai cross loading antara indikator dan variabel latennya lebih besar daripada dengan variabel laten lain.

\section{3) Internal Consistency Reliability}

Semua indikator pada variabel laten memiliki nilai cronbach's aplha dan composite reliability pada yang dihasilkan melebihi angka 0,6 dan 0,7. Nilai tertinggi dimiliki oleh variabel financial incentives yaitu 0,903 dan 0,940 .

Selanjutnya dilakukan pengujian inner model, berikut merupakan beberapa indikator yang digunakan.

\section{1) Koefisien $R^{2}$. Nilai $R$-square $\left(R^{2}\right)$}

Koefisien $R^{2}$. Nilai $R$-square $\left(R^{2}\right)$ yang dihasilkan untuk variabel adoption intention sebesar 0,818 sedangkan untuk variabel perceived value sebesar 0,850. Hal ini mengindikasikan bahwa persentase keberagaman data pada variabel adoption intention dan perceived value tergolong substansial (kuat).

2) Cross-Validated Redundancy $\left(Q^{2}\right)$

Nilai $Q$-square $\left(Q^{2}\right)$ yang dihasilkan ialah 0,972 sehingga dapat dijelaskan bahwa besarnya keragaman dari data penelitian dapat dijelaskan oleh model struktural sebesar $97,2 \%$. 


\section{3) Goodness of Fit (GOF)}

Nilai GOF yang dihasilkan ialah 0,810 sehingga mengindikasikan bahwa model penelitian dapat dikatakan fit karena nilai goodness of fit (GOF) melebihi nilai 0,38.

\section{Uji Hipotesis}

Uji hipotesis dilakukan dengan melihat nilai path coefficient yang dihitung melalui Bootstrapping dengan menggunakan metode PLS-SEM. Hipotesis penelitian dapat diterima apabila memiliki nilai $p$ value lebih kecil dari 0,05 . Berdasarkan hasil uji hipotesis (Tabel 5) dapat diketahui beberapa hal sebagai berikut:

1. Dari 11 hipotesis yang diajukan, terdapat 6 hipotesis yang diterima karena $p$ value lebih besar dari signifikansi 0,05 . Hipotesis yang diterima yaitu $\mathrm{H} 1$, $\mathrm{H} 2 \mathrm{~A}, \mathrm{H} 2 \mathrm{~B}, \mathrm{H} 2 \mathrm{C}, \mathrm{H} 3 \mathrm{C}$ dan H5B.

2. Nilai signifikan $p$ value terendah yaitu sebesar 0,000 terdapat pada Hipotesis $2 \mathrm{C}$ yang menguji hubungan antara driving enjoyment benefit terhadap perceived value

3. Nilai signifikan $p$ value tertinggi yaitu sebesar 0,797 yang menunjukkan bahwa hipotesis ditolak terdapat pada Hipotesis 4A yang menguji pengaruh moderasi variabel environmental innovativeness terhadap perceived value dan niat adopsi pada mobil LCEV.

\section{E. Pembahasan Hipotesis}

Bagian ini menjelaskan mengenai pembahasan dari setiap hasil hipotesis penelitian.

1) HI Perceived value berpengaruh positif terhadap niat adopsi pada mobil Low Carbon Emission Vehicle (LCEV).

Nilai yang ditawarkan pada mobil LCEV tidak hanya keunggulan fungsional tetapi juga partisipasi yang diberikan pada lingkungan seperti pengurangan emisi karbondioksida dan pengalaman secara emosional bagi responden yang pernah mengendarai mobil LCEV [5]. Berbagai macam nilai inilah menyebabkan responden mempertimbangkan untuk mengadopsi mobil karena telah merasakan value yang dimiliki mobil LCEV.

2) H2A. Operational economic benefit berpengaruh positif terhadap perceived value pada mobil Low Carbon Emission Vehicle (LCEV).

Mobil LCEV memiliki manfaat utama yaitu biaya bahan bakar lebih ekonomis dibandingkan dengan mobil konvensional [5][25]. Responden merasakan bahwa mobil yang dikendarai lebih hemat biaya bahan bakar dan biaya perawatan daripada mobil konvensional sehingga membentuk sikap positif pada mobil LCEV.

3) $H 2 B$. Eco-friendly benefit berpengaruh positif terhadap perceived value pada mobil Low Carbon Emission Vehicle (LCEV).

Mobil LCEV memiliki citra lingkungan yang positif karena kemampuan mobil menghasilkan emisi karbondioksida rendah sehingga mampu mengurangi polusi udara [26]. Citra positif yang dimiliki oleh mobil LCEV inilah yang membentuk persepsi responden bahwa dengan mengendarai mobil LCEV maka mereka telah berkontribusi menjaga lingkungan sekitar.
4) H2C. Driving enjoyment benefit berpengaruh positif terhadap perceived value pada mobil Low Carbon Emission Vehicle (LCEV).

Mobil LCEV menawarkan kesenangan dan kenyamanan berkendara karena memancarkan kebisingan dan getaran yang rendah [26]. Responden merasakan sensasi tersendiri saat mengendari mobil LCEV dibandingkan mobil konvensional. Hal ini karena produk otomotif tersebut tergolong baru dan hanya beberapa orang yang memiliki kesempatan untuk memiliki pengalaman berkendara.

5) H3A. Price and battery cost berpengaruh negatif terhadap perceived value pada mobil Low Carbon Emission Vehicle (LCEV).

Harga dan biaya baterai memiliki pengaruh negatif terhadap perceived value pada mobil LCEV karena dianggap mengambat niat adopsi [9]. Namun, responden tidak menganggap harga dan biaya baterai mengurangi perceived value karena mobil LCEV merupakan produk baru di pasar otomotif Indonesia dan menawarkan berbagai manfaat bagi target konsumennya.

6) H3B. Technological performance risk berpengaruh negatif terhadap perceived value pada mobil Low Carbon Emission Vehicle (LCEV).

Sikap konsumen terhadap kinerja mobil LCEV dan rentang kecemasan terbukti menjadi penghalang dalam mengadopsi mobil LCEV [9]. Namun, kekhawatiran responden tentang kinerja teknologi belum menjadi kendala utama dalam mengendarai mobil LCEV karena risiko yang dirasakan juga tidak terlalu tinggi.

7) H3C. Charging risk berpengaruh negatif terhadap perceived value pada mobil Low Carbon Emission Vehicle (LCEV).

Charging risk menjadi risiko yang sering terjadi dan dihadapi saat mengendarai mobil LCEV [9]. Charging risk yang dirasakan responden seperti stasiun pengisian baterai yang susah ditemui, waktu pengisian baterai yang lama hingga jarak maksimum yang dapat ditempuh setelah melakukan pengisian daya. Adanya risiko inilah yang mengurangi value mobil dan harus diperhatikan karena menjadi penentu penting kesediaan dalam membeli dan mengadopsi mobil LCEV [3].

8) H4A. Environmental innovativeness secara positif memoderasi hubungan antara perceived value dan niat adopsi mobil Low Carbon Emission Vehicle (LCEV).

Inovasi pribadi yang tinggi akan membentuk niat yang besar dalam menerima inovasi daripada konsumen dengan tingkat inovasi rendah [27]. Namun sikap environmental innovativeness yang dimiliki oleh responden tidak mempengaruhi niat adopsi. Hal ini mengindikasikan berbagai produk ramah lingkungan yang dimiliki responden tidak mempengaruhi niat adopsi mereka pada mobil LCEV.

9) H4B. Environmental concern secara positif memoderasi hubungan antara perceived value dan niat adopsi mobil Low Carbon Emission Vehicle (LCEV).

Environmental concern tidak memoderasi hubungan antara perceived value dan niat adopsi, namun memiliki pengaruh langsung terhadap niat adopsi pada mobil LCEV. 
Adanya pengaruh langsung didukung oleh penelitian Wang et al. (2014) bahwa konsumen dengan kepedulian lingkungan tinggi lebih bersedia untuk mengadopsi mobil LCEV.

10) H5A. Financial incentives secara positif memoderasi hubungan antara perceived value dan niat adopsi mobil Low Carbon Emission Vehicle (LCEV).

Financial incentives tidak memoderasi hubungan antara perceived value dan niat adopsi, namun memiliki pengaruh langsung terhadap niat adopsi pada mobil LCEV. Adanya pengaruh langsung didukung oleh penelitian Wang et al. (2017) bahwa dengan adanya insentif keuangan akan memicu niat masyarakat untuk mengadopsi mobil LCEV serta dapat menumbuhkan pasar mobil LCEV.

11) H5B. Non-financial incentives secara positif memoderasi hubungan antara perceived value dan niat adopsi mobil Low Carbon Emission Vehicle (LCEV).

Non-financial policies memoderasi secara positif hubungan perceived value dengan niat adopsi. Hal ini mengindikasikan adanya kebijakan non-keuangan yang diberikan seperti pengadaan infrastruktur pengisian daya di berbagai kota dan previllige khusus memperkuat hubungan antara perceived value terhadap niat adopsi mobil LCEV.

\section{F. Implikasi Manajerial}

Perusahaan perlu melakukan membuat green campaign dalam bentuk video dengan mengenalkan mobil LCEV sebagai mobil masa depan masyarakat Indonesia dan social event yang dikemas dalam konsep peduli sekitar. Tidak hanya itu, perusahaan otomotif dapat bekerja sama dengan start-up penyewaan mobil untuk menawarkan pengalaman berkendara bagi masyarakat Indonesia yang ingin merasakan sensasi mengendarai mobil LCEV, namun belum mampu untuk membelinya. Perusahaan juga perlu memberikan jaminan resale value dan test drive sebelum membeli untuk meyakinkan masyarakat mengenai kinerja mobil LCEV. Untuk menarik sikap pro-lingkungan, perusahaan dapat membuat web series dengan melibatkan public figure yang menekankan tentang gaya hidup ramah lingkungan.

Disisi lain, peran pemerintah juga diperlukan untuk meningkatkan permintaan pasar mobil LCEV. Insentif keuangan yang diberikan pada calon konsumen seperti pengenaan PPnBM mobil berdasarkan tingkat emisi yang dihasilkan, subsidi pembelian dan bantuan kredit. Sedangkan kebijakan non-keuangan yang dapat diberikan seperti pengadaan ultra fast charging yang disediakan di beberapa kota besar, pembebasan ganjil genap, pemberian diskon tarif tol hingga program sosialisasi untuk mengedukasi masyarakat mengenai mobil LCEV.

\section{V.SIMPULAN DAN SARAN}

\section{A. Simpulan}

Berdasarkan hasil pengolahan data dan analisis yang telah dilakukan sebelumnya, perceived value berpengaruh positif signifikan pada niat adopsi. Hal ini menunjukkan bahwa semakin tinggi nilai yang dirasakan akan meningkatkan niat adopsi responden akan mobil LCEV. Operational economic benefit, eco-friendly benefit dan driving enjoyment berpengaruh positif signifikan pada perceived value sedangkan price and battery cost dan technological perfomance risk tidak berpengaruh signifikan pada perceived value. Disisi lain, charging risk berpengaruh negatif signifikan pada perceived value. Pada variabel moderasi environmental innovativeness, environmental concern dan financial incentives tidak memoderasi hubungan perceived value dan niat adopsi sedangkan nonfinancial policies memoderasi positif hubungan perceived value dengan niat adopsi. Hal ini menunjukkan bahwa kebijakan non-keuangan yang diberikan seperti pengadaan infrastruktur pengisian daya akan memperkuat perceived value yang diterima sehingga meningkatkan niat adopsi mobil LCEV.

\section{B. Limitasi dan Saran}

Penelitian ini memberikan kesempatan bagi seluruh masyarakat untuk berpartisipasi sebagai responden yang sesuai dengan kriteria penelitian. Akan tetapi, mayoritas responden berasal dari Pulau Jawa, sehingga responden hanya terfokus pada wilayah tersebut dikarenakan masih sedikitnya masyarakat yang pernah mengendarai mobil Low LCEV khususnya yang berjenis plug-in hybrid dan mobil listrik. Oleh karena itu, penelitian ini belum sepenuhnya mewakili masyarakat di Negara Indonesia. Selanjutnya, objek penelitian kurang spesifik untuk jenis mobil LCEV tertentu seperti mobil hybrid, mobil plug-in hybrid ataupun mobil listrik serta terdapat beberapa jenis pekerjaan seperti supir yang pernah menggunakan namun belum tercermin sebagai subjek dalam penelitian ini.

Penulis menyarankan untuk penelitian selanjutnya mempertimbangkan beberapa hal yaitu melakukan spesifikasi penelitian pada satu jenis mobil baik hybrid, plug-in dan mobil listrik dengan membandingkan beberapa merek ternama, membagi responden ke beberapa wilayah (quota sampling) sehingga dapat mewakili masyarakat Indonesia dan mengeksplorasi lebih dalam mengenai peran pemerintah baik dari segi keuangan maupun non-keuangan.

\section{DAFTAR PUSTAKA}

[1] Kemenperin, "Geliat Industri Otomotif Semakin Ngebut," Siaran Pers, 2018. [Online]. Available: https://kemenperin.go.id/artikel/197 53/Geliat-Industri-Otomotif-Semakin-Ngebut. [Accessed: 22-Oct2019].

[2] Gaikindo, "Indonesian Automobile Industry Data," Gaikindo.or.id, 2019. [Online]. Available: https://www.gaikindo.or.id/indonesianautomobile-industry-data/. [Accessed: 10-Oct-2010].

[3] Detik.com, "GIIAS 2019: Mobil Hybrid Toyota yang Kian Populer," Detik.com, 2019. [Online]. Available: https://oto.detik.com/event/d4637732/giias-2019-mobil-hybrid-toyota-yang-kian-populer. [Accessed: 07-Oct-2019].

[4] CNN Indonesia, "Survei: Alasan Orang Indonesia Enggan Beli Kendaraan Listrik," cnnindonesia.com, 2018. [Online]. Available: https://www.cnnindonesia.com/teknologi/20180712093702-384313488/survei-alasan-orang-indonesia-enggan-beli-kendaraan-listrik. [Accessed: 25-Oct-2019].

[5] M. K. Kim, J. Oh, J. H. Park, and C. Joo, "Perceived value and adoption intention for electric vehicles in Korea: Moderating effects of environmental traits and government supports," Energy, vol. 159, pp. 799-809, 2018.

[6] M. Featherstone, Posmodernisme dan Budaya Konsumen (Terjemahan). Yogyakarta: Pustaka Belajar, 2008.

[7] S. Wang, J. Wang, J. Li, J. Wang, and L. Liang, "Policy implications for promoting the adoption of electric vehicles: Do consumer ' $\mathrm{s}$ knowledge , perceived risk and fi nancial incentive policy matter?," Transp. Res. Part A, vol. 117, no. January, pp. 58-69, 2018. 
[8] R. Junquera, B ; Moreno, B ; Alvarez, "Analyzing consumer attitudes towards electric vehicle purchasing intentions in Spain: technological limitations and vehicle confidence," Technol Forecast Soc Chang., vol. 109, pp. 6-14, 2016.

[9] Z. Y. She, Qing Sun, J. J. Ma, and B. C. Xie, "What are the barriers to widespread adoption of battery electric vehicles? A survey of public perception in Tianjin, China," Transp. Policy, vol. 56, no. July 2016, pp. 29-40, 2017.

[10] Kompas, "PLN Sudah Punya 7.000 Lebih SPLU di Indonesia," Kompas.com, 2019. [Online]. Available: https://otomotif.kompas com/read/2019/09/11/084100915/pln-sudah-punya-7.000-lebih-spludi-indonesia. [Accessed: 07-Oct-2019].

[11] A. Zubaryeva, A; Thiel, C; Barbone, E; Mercier, “Assessing factors for the identification of potential lead markets for electrified vehicles in Europe: expert opinion elicitation," J. Technol. Forecast. Soc. Chang., vol. 79, no. 9, pp. 1622-1637, 2012.

[12] Kemenperin, "Pasar Global Produk Ramah Lingkungan," Berita Industri, 2014. [Online]. Available: https://kemenperin.go.id/artikel/8810/PasarGlobal-Produk-RamahLingkungan. [Accessed: 10-Nov-2019].

[13] Y. Wang, S.; Fan, J.; Zhao, D.; Yang, S.; Fu, "Predicting consumers' intention to adopt hybrid electric vehicles: using an extended version of the theory of planned behavior model," J. Transp., vol. 43, no. 1, pp. 123-143, 2014.

[14] N. White, LV; Sintov, "You are what you drive: Environmentalist and social innovator symbolism drives electric vehicle adoption intentions," J. Transp. Res. Part A, vol. 99, pp. 94-113, 2017.

[15] A. Doyle and T. Muneer, A case study for Northern Europe. Elsevier Inc., 2017.

[16 ] H.-W. Kim, H. C. Chan, and S. Gupta, "Value-based Adoption of Mobile Internet: An empirical investigation," Decis. Support Syst., vol. 43, no. 1, pp. 111-126, 2007.

[17] V. . Zeithaml, "Consumer perceptions of price, quality, and value: a means-end model and synthesis of evidence," J. Mark., vol. 52, no. 3, pp. 2-22, 1998.

[18] G. Schuitema, J. Anable, S. Skippon, and N. Kinnear, "The role of instrumental, hedonic and symbolic attributes in the intention to adopt electric vehicles," Transp. Res. Part A Policy Pract., vol. 48, pp. 39-49, 2013

[19] E. van der Werff, L. Steg, and K. Keizer, "The value of environmental self-identity: The relationship between biospheric values, environmental self-identity and environmental preferences, intentions and behaviour," J. Environ. Psychol., vol. 34, pp. 55-63, 2013.

[20] R. Caiazza, "A cross-national analysis of policies affecting innovation diffusion," J. Technol. Transp., vol. 41, no. 6, pp. 14061419,2016

[21] S. Foxall, G.R.; Goldsmith, R.E.; Brown, Consumer Psychology for Marketing International. London: Thomson Business Press, 1998.

[22] E. Graham-Rowe et al., "Mainstream consumers driving plug-in battery-electric and plug-in hybrid electric cars: A qualitative analysis of responses and evaluations," Transp. Res. Part A Policy Pract., vol. 46, no. 1, pp. 140-153, 2012.

[23] N. K. Malhotra, Marketing Research: An Applied Orientation, 6th ed. New Jersey: Pearson, 2010.

[24] J. F. Hair, W. C. Black, B. J. Babin, and R. E. Anderson, Multivariate Data Analysis. 2010.

[25] J. Hagman, S. Ritzén, J. J. Stier, and Y. Susilo, "Total cost of ownership and its potential implications for battery electric vehicle diffusion," Res. Transp. Bus. Manag., vol. 18, pp. 11-17, 2016.

[26] S. Bickert, A. Kampker, and D. Greger, "Developments of CO2 emissions and costs for small electric and combustion engine vehicles in Germany," Transp. Res. Part D Transp. Environ., vol. 36, pp. 138-151, 2015.

[27] E. M. Rogers, Diffusion of Innovations, 4th edn. New York, NY: The Free Press, 1995 